\title{
Analisis Pelaksanaan Program Kemitraan Bidan dan Dukun Ditinjau Dari Aspek Input, Proses dan Output di Wilayah Dinas Kesehatan Kabupaten Fakfak Provinsi Papua Barat
}

\author{
Elzina De Fretes*, Hardi Warsono**, Ayun Sriatmi** \\ *Alumni Magister Ilmu Kesehatan Masyarakat Universitas Diponegoro **Staf Pengajar Program \\ Magister Ilmu Kesehatan Masyarakat Universitas Diponegoro
}

\begin{abstract}
ABSTRAK
Jumlah tenaga bidan di kabupaten Fakfak tahun 2012 adalah 108 orang, jumlah dukun bersalin 191 orang, yang terlatih 79(41\%) dan tidak terlatih 112 (59\%). Jumlah dukun lebih banyak dari bidan menyebabkan masih tingginya peran dukun dalam pertolongan persalinan. Cakupan persalinan nakes belum mencapai target. Penilitian ini bertujuan untuk menganalisis pelaksanaan program kemitraan bidan dan dukun ditinjau dari aspek input, process dan output diwilayah kerja Dinas Kesehatan Kabupaten Fakfak. Jenis penelitian adalah kualitatif yang disajikan secara deskriptif eksploratif melalui wawancara mendalam. Subjek penelitian

pencatatan dan pelaporan khusus kegiatan kemitraan, selama ini menggunakan format yang ada di laporan KIA. Aspek Output masih terdapat 195 (89\%) dukun belum bermitra dari 219 dukun yang ada, cakupan $\mathrm{K} 1, \mathrm{~K} 4$ dan persalinan oleh tenaga kesehatan dari tahun 2011 ke 2012 cenderung menurun. Saran bagi DKK dan Puskesmas untuk mengupayakan tetap berlangsungnya kemitraan dengan dukungan seluruh aspek diantaranya rekruitment tenaga bidan, ketersediaan sarana prasarana, dana serta sosialisasi kepada tokoh masyarakat, dan membiayai sekolah bidan anak atau cucu dukun untuk membatasi munculnya dukun baru.
\end{abstract} adalah bidan dan dukun yang bermitra. Data dikumpulkan dengan teknik wawancara mendalam. Pengolahan dan analisis data menggunakan analisis isi. Hasil penelitian ditinjau dari aspek Input : 1) Tenaga pelaksana, pengetahuan yang dimiliki oleh bidan dan dukun baru sebatas pada kerjasama dalam menolong persalinan.; 2) Alokasi dana khusus program belum disediakan, saat ini menggunakan dana BOK namun belum mencukupi; 3) Sarana khusus program belum ada, saat ini menggunakan sarana prasarana puskesmas dan polindes namun mengalami keterbatasan. Ditinjau dari aspek Process 1) Perencanaan program, bidan dan dukun melakukan pendataan bumil, bulin, bufas dan jumlah dukun; 2) Pelaksanaan belum berjalan baik karna bidan yg selalu tidak berada ditempat bila dihubungi oleh dukun dan akses yang sulit. Sosialisasi lintas sektor (Toma dan Toga) dan magang dukun belum dilakukan karena keterbatasan dana ; 3) Tidak dilakukan
Kata Kunci : Program Kemitraan Bidan Dukun, Input, Process dan Output

\section{PENDAHULUAN}

Persalinan di dukun masih merupakan pilihan bagi ibu hamil di Propinsi Papua Barat. Pada umumnya dukun bersalin diangkat berdasarkan kepercayaan masyarakat setempat atau merupakan pekerjaan yang sudah turun temurun dari nenek moyang atau keluarganya dan biasanya sudah berumur 40 tahun ke atas. ${ }^{7}$

Berdasarkan data Profil Kesehatan Dinas Kesehatan Kabupaten Fakfak, Angka Kematian Ibu (AKI) pada tahun 2009 sebesar 759 per $100.000 \mathrm{KH}$ atau sebesar 12 kasus, yang secara bertahap mengalami penurunan di tahun 2010 menjadi 416 per $100.000 \mathrm{KH}$ atau sebesar 7 kasus dan pada tahun 2011 menjadi 187 per $100.000 \mathrm{KH}$ atau 3 kasus akan tetapi pada tahun 2012 kembali terjadi kenaikan 
menjadi sebesar 394 per $100.000 \mathrm{KH}$ atau sebesar 5 kasus. Penyebab kematian adalah 3 ibu karna partus lama dengan komplikasi malaria tropika, 1 ibu dengan anemia $\mathrm{Hb}$ dibawah 8 gram $\%, 1$ ibu dengan anemia berat dan preeklamsi dan 1 orang ibu dengan preeklamsi. Lima kematian ibu ini terjadi di Rumah Sakit Umum akibat terlambat dirujuk oleh dukun dan keluarga yang sebelumnya telah melakukan intervensi di rumah dengan akses yang jauh dari pelayanan kesehatan.

Angka Kematian Bayi (AKB) mengalami kenaikan dari 28 per 1000 kelahiran hidup pada tahun 2011, menjadi sebesar 34 per 1000 kelahiran hidup atau sebesar 41 kasus di tahun 2012. ${ }^{8}$ Kematian bayi terbanyak pada bayi lahir hidup dan mati ada 22 bayi, umur 0-7 hari 12 bayi, umur 8-28 hari 1 bayi dan umur 29 hari - 11 bulan ada 8 bayi. Kematian bayi ini terbanyak karena asfiksia yang disebabkan karena ibu yang mengalami partus macet dan lama.

Jumlah tenaga bidan di kabupaten Fakfak tahun 2012 ada 108 orang. Jumlah dukun bersalin di Kabupaten Fakfak 191 orang diantaranya yang terlatih 79 orang atau sebesar $41 \%$ dan 112 orang tidak terlatih (59\%). Hal ini menyebabkan masih tingginya peran dukun dalam pertolongan persalinan di Kabupaten Fakfak dan telah menjadi perhatian DKK untuk meningkatkan cakupan persalinan nakes melalui Program Kemitraan Bidan dan Dukun. Program tersebut mulai disosialisasikan tahun 2007. Dari 79 dukun terlatih yang telah mendapat sosialisasi sebanyak $8(10 \%)$ orang dukun yang melakukan kemitraan dengan bidan.

Melihat fenomena yang ini, maka perlu dilakukan analisis pelaksanaan program kemitraan bidan dan dukun ditinjau dari aspek input, process an output yang dapat dijadikan bahan pertimbangan untuk perbaikan pelaksanaan program kedepannya.

\section{METODE PENELITIAN}

Jenis penelitian adalah kualitatif yang disajikan secara deskriptif eksploratif dengan metode wawancara mendalam. Sebagai informan utama adalah bidan dan dukun yang bermitra di wilayah kerja Dinas kesehatan Kabupaten Fakfak, yang berjumlah 4 orang, sedangkan informan triangulasi nakes adalah Kabid Kesga, 2 kepala Puskesmas, 2 Bidan yang tidak bermitra, dan informan triangulasi non nakes yakni 2 orang dukun yang tidak bermitra dan 2 orang ibu bersalin. Hal yang dianalisis dalam pelaksanaan program kemitraan bidan dan dukun ditinjau dari aspek input (tenaga, dana, sarana dan metode), proses (perencanaan, pelaksanaan, penilaian) dan output (jumlah dukun yang bermitra, jumlah rujukan dukun, cakupan $\mathrm{K} 1$ dan $\mathrm{K} 4$, persalinan nakes, peserta KB pasca salin). Pengumpulan data dilakukan dengan wawancara mendalam (indepth interview), observasi dan telaah dokumen. Pengolahan dan analisis data dilakukan dengan content analysis.

\section{HASIL DAN PEMBAHASAN \\ Input Dalam Program Kemitraan Bidan Dukun}

Pengetahuan bidan tentang kemitraan bidan dan dukun dipahami hanya sebagai suatu bentuk kerjasama yang dilakukan dengan dukun dalam menolong persalinan. Sementara pemahaman dukun tentang kemitraan adalah dengan selalu melibatkan bidan dalam menolong persalinan karena belum pengalaman

.Menjalin kerja sama yang baik .... akan menolong dua nyawa sekaligus bayi dan ibu....(IU Bd 2) ......tujuannya minta bantu karna saya khan belum berpengalaman (IU Dk 3)

Hal tersebut berarti pengetahuan bidan dan dukun tentang program kemitraan masih kurang, bidan dan dukun belum memahami prinsip keterbukaan, kesetaraan dan kepercayaan dalam upaya menyelamatkan ibu dan bayi, seharusnya bidan mengetahui tujuan kemitraan adalah untuk meningkatkan pelayanan antenatal, persalinan, pelayanan nifas dan rujukan oleh dukun ke tenaga kesehatan yang kompeten; meningkatkan alih peran dukun dari penolong persalinan menjadi mitra bidan dalam merawat ibu nifas dan bayinya; meningkatkan peran dukun sebagai kader kesehatan ibu dan bayi baru lahir. 
Dinas Kesehatan Kabupaten tidak mengalokasikan dana khusus program kemitraan bidan dan dukun, namun kegiatan program ini di laksanakan dengan menggunakan dana BOK yang langsung dikelola oleh masing-masing puskesmas sesuai kebutuhan di wilayahnya. Kecukupan anggaran yang disediakan belum diketahui untuk semua wilayah puskesmas. Hal tersebut karena baru dianggarkan dalam dana BOK pada tahun 2013 dan penentuan jumlah anggaran untuk kegiatan tersebut belum didasari oleh jumlah rujukan dukun pada tahun sebelumnya, tetapi berdasarkan alokasi dana yang tersedia.

.....Baru tahun ini saya tidak tau cukup atau tidak bu, ng tapi harapan kita si cukuplah bu...(IU Bd 2)

Bantuan Operasional Kesehatan dikucurkan dengan tujuan untuk meningkatkan upaya pelayanan kesehatan masyarakat melalui kegiatan promotif dan preventif Puskesmas. Puskesmas diberikan wewenang dalam pemanfaatan dana tersebut sesuai ruang lingkup yang telah ditetapkan. ${ }^{43}$ Ketersediaan dana BOK harus dimanfaatkan oleh Puskesmas untuk melaksanakan kegiatan-kegiatan yang dipandang dapat menjadi daya ungkit terhadap pencapaian tujuan program di puskesmas. ${ }^{45}$

Sarana merupakan salah satu unsur masukan yang menunjang pelaksanaan kemitraan bidan dengan dukun. Sarana yang dimaksud adalah sarana prasarana KIA di puskesmas, polindes dan sarana transportasi rujukan. Informan utama bidan dan dukun menyatakan bahwa diwilayahnya terdapat puskesmas rawat inap dan polindes yang juga dilengkapi dengan ruang untuk bersalin. Salah satu informan utama bidan menyatakan mengalami kekurangan peralatan dan bahan habis pakai untuk pelayanan pemeriksaan kehamilan seperti tidak tersedia doppler dan alat pemeriksaan laboratorium sederhana untuk membantu dalam menegakkan diagnosa kebidanan seperti $\mathrm{Hb}$ Sahli dan reagennya.
Tidak ada Sarana prasarana khusus program, saat ini menggunakan sarana prasarana KIA yang ada di Puskesmas dan Polindes namun belum memadai. Selain itu dibutuhkan sarana prasarana transportasi dalam kemitraan bidan dan dukun. Semua informan utama bidan dan dukun menyatakan ada sarana transportasi rujukan yaitu 1 mobil ambulance dan transportasi laut yakni jonson yang saat ini dalam keadaan rusak.Ketersediaan sarana prasarana merupakan faktor penentu kinerja sebuah kebijakan.

Menurut semua informan utama bidan dan dukun menyatakan bahwa dalam pelaksanaan Program Kemitraan Bidan dan ..kita data banyaknya bumil, jumlah dukun yang aktif menolong persalinan yang lama maupun dukun yang baru serta melakukan pendekatan... (IU Bd 1)

.....kitong lapor berapa jumlah ibu yang hamil dan kalo ada dukun yang baru di kitong pu wilayah...... (IU Dk 3) 
Perencanaan merupakan fungsi terpenting dalam manajemen, karena fungsi perencanaan akan menentukan fungsi-fungsi manajemen yang lain.

\section{Pelaksanaan Kemitraan Bidan dan Dukun}

Dalam pelaksanaan kemitraan bidan dengan dukun, informan utama bidan menyatakan kegiatan yang dilakukan adalah pendekatan ke dukun, melibatkan dukun dalam pendataan ibu hamil, menolong

\section{Kotak 30}

.....setelah sosialisasi dengan dukun, saya pendekatan dengan mereka, libatkan dukun dalam pendataan ibu hamil, saya juga kasih ingat kalo ada ibu yang melahirkan jangan lupa kasih tau saya. Waktu tolong persalinan sama-sama, saya juga ajarkan langsung bagaimana merawat tali pusat. Kalau saya dipanggil untuk tolong persalinan kadang ajak dukun,........(IU Bd 1)

Informan utama dukun juga menyatakan, bila ada persalinan menghubungi bidan sehingga pertolongan persalinan ditolong bersama-sama atau persalinan ditolong dukun sendirian karena dianggap mudah, setelah selesai menolong persalinan baru dilaporkan ke bidan. Kedua Informan utama dukun juga menyatakan bahwa mereka sering dipanggil

kalo ada yang panggil kitong untuk melahirkan, katong harus panggil bidan. Sekarang kitong tolong persalinan sama-sama dengan bidan dorang, tapi biasa beta lia lai kalo tra susah kadang beta tolong sandiri nanti baru lapor bidan, kitong juga disuruh lapor dan catat ibu-ibu yang hamil, kadang-kadang ada yang beta bawa ke puskesmas priksa. Biasa lai dong panggil beta pi tolong orang melahirkan di kampung sabla, yang paling jauh itu di karas, jadi pi musti naik jonson, kalo beta tolong bagitu beta biasa panggil bidan juga sama-sama... (IU Dk 3)

Cuma kalo ada tolong melahirkan di tampa lain, beta malu hati panggil bidan, habis balom kenal... (IU Dk 4)

Dukun setelah mendapatkan sosialisasi kemitraan bidan dan dukun memahami bahwa pertolongan persalinan harus melibatkan bidan, namun dalam pelaksanaanya masih banyak persalinan yang masih ditolong oleh dukun yang bermitra dengan sendirian, setelah menolong persalinan baru dilaporkan ke bidan di puskesmas, laporan dukun ini akan diklem oleh bidan sebagai persalinan nakes karena dilaporkan oleh dukun yang bermitra. Pertolongan persalinan oleh dukun yang bermitra tidak terbatas dalam wilayah tempat tinggalnya saja tetapi sering juga di pangil di kampung-kampung tetangga yang juga cukup jauh dari tempat tinggal dan menyeberangi lautan dan tidak selalu melibatkan bidan.

Dalam pelaksanaan langkah-langkah program kemitraan bidan dan dukun, ada beberapa langkah yang belum dilaksanakan oleh bidan yaitu belum ada susunan rencana kerja kegiatan kemitraan dengan menetapkan pembagian tugas sesuai dengan peran dan tanggung jawabnya, belum dilakukan untuk menolong persalinan di luar wilayah tempat tinggal yang kadang harus menyeberangi lautan, walaupun demikian salah satu informan utama dukun selalu melibatkan bidan sedangkan salah satu informan utama dukun tidak melibatkan bidan karena belum kenal sehingga merasa malu.

persalinan dengan dukun, memberikan
penjelasan ke dukun waktu menolong persalinan bersama dengan mengajarkan tentang perawatan tali pusat. Salah satu informan utama bidan juga kadang melibatkan dukun setempat jika dipanggil dengan pertimbangan diharapkan dukun juga akan memanggil bidan nantinya bila ada ibu yang memanggil dukun untuk melahirkan.

sosialisasi kesepakatan kemitraan bidan dengan dukun.

Kesepakatan antara bidan dengan
Desa/Lurah dan Kepala Puskesmas belum pernah dibuat. Belum ada atau tidak adanya kesepakatan tertulis antara bidan dengan dukun, menunjukkan bahwa sosialisasi belum dilaksanakan sebagaimana mestinya.

\section{Output Dalam Kemitraan Bidan Dengan Dukun}

Jumlah dukun bermitra tahun 2011 terdapat 174 dukun di Kabupaten Fakfak dan 160 dukun $(92 \%)$ diantaranya belum bermitra.

Jumlah rujukan dukun, informan utama bidan dan dukun menyatakan, terdapat rujukan dari dukun ke bidan, namun mereka tidak pernah melakukan pencatatan jumlah rujukan dari dukun. Informan triangulasi nakes kedua kepala puskesmas membenarkan pernyataan informan utama bidan dan dukun yang menyatakan bahwa selama ini dukun juga merujuk ibu hamil, bulin dan juga nifas 
ke bidan, namun pencatatannya jadi satu dalam laporan KIA sehingga tidak ditahu jumlah rujukan khusus dari dukun berapa.

Berdasarkan target cakupan K1 Kabupaten Fakfak tahun 2011 dan 2012 adalah 100\%. Tahun 2011 Ada 7 dari 9 puskesmas yang mempunyai cakupan K1 mencapai bahkan melampaui target yang telah ditentukan. Namun pada tahun 2012 cakupan K1 rata-rata mengalami penurunan, hanya 4 puskesmas yakni Puskesmas Weri, Degen, Kramomongga dan Fakfak Kota yang mencapai target sementara 5 puskesmas lainnya dibawah target pencapaian yakni Puskesmas Werba, Fakfak Tengah, Bomberay, Kokas dan Karas.

Cakupan K4 tahun 2011 adalah 95\% dan target cakupan tahun 2012 79\%. Pada tahun 2011 ada 2 puskesmas yang cakupannya mencapai target yakni puskesmas Fakfak Kota dan Bomberay sedangkan 7 puskesmas cakupannya dibawah target. Tahun 2012 mengalami penurunan, 9 puskesmas tidak mencapai target cakupan.

Kemitraan bidan dengan dukun belum memberikan kontribusi terhadap cakupan pelayanan antenatal (K1 dan K4), yang mengalami penurunan di tahun 2012. Cakupan pelayanan antenatal (K1 dan K4) merupakan produk yang dihasilkan dari kemitraan bidan dengan dukun, sehingga menjadi salah satu indikator keberhasilan program KIA, termasuk kemitraan bidan dengan dukun dan. Bila sosialisasi kemitraan bidan dengan dukun dilakukan dengan optimal kepada masyarakat termasuk dukun, maka dukun melaksanakan peran memotivasi dan mengantar ibu hamil untuk periksa hamil ke bidan, diperkirakan akan memberikan output peningkatan cakupan pelayanan antenatal (K1 dan K4). Tahun 2012 semua puskesmas mengalami penurunan angka cakupan yakni dibawah 95\% persalinan nakes hanya puskesmas Fakfak saja yang mencapai target walaupun mengalami sedikit penurunan dari tahun sebelumnya. Bila sosialisasi kemitraan bidan dengan dukun dilakukan dengan optimal kepada masyarakat termasuk dukun, maka dukun akan melaksanakan peran memotivasi dan merujuk ibu bersalin ke bidan atau tenaga kesehatan, sehingga cakupan pertolongan persalinan oleh tenaga kesehatan akan meningkat.

Hasil wawancara mendalam terhadap informan utama bidan dan dukun terkait tidak ditemukannya data akseptor KB pasca persalinan, diperoleh informasi 2 informan utama menyatakan mereka tidak memisahkan akseptor baru KB yang masa nifas dan bukan masa nifas.

Ibu yang masuk KB sebelum 40 hari ada, tapi karna di register KB ndak diminta data itu, jadi saya tidak laporkan dan tidak tau berapa jumlah peserta KB baru setelah melahirkan.(IU Bd 1)

....kalau akseptor KB pasca salin si kita tidak ada data khususnya bu, di laporan KB, akseptor baru tidak dipisahkan dipisahkan, mau dia baru habis melahirkan atau yang masih menunda kehamilan atau yang lainnya hanya dicatat sebagai akseptor baru saja.(IU Bd 2)

Bila data output yang dimaksudkan tidak ada, maka keberhasilan kemitraan sehubungan dengan dengan jumlah akseptor $\mathrm{KB}$ selesai melahirkan tidak bisa dievaluasi. Dukun sangat berpengaruh dalam memotivasi ibu nifas dan keluarga untuk ber-KB setelah melahirkan akan memberikan output jumlah akseptor $\mathrm{KB}$ pasca bersalin meningkat. Hal tersebut merupakan indikator keberhasilan kemitraan bidan dengan dukun.

\section{KESIMPULAN}

Hasil penelitian tentang pelaksanaan Program Kemitraan Bidan dan Dukun di lingkungan kerja Dinas Kesehatan Kabupaten Fakfak yang telah dilakukan maka ; Ditinjau
Dari Aspek Input. Faktor Tenaga meliputi pengetahuan. Pengetahuan bidan dan dukun masih kurang,. Tugas tambahan dan kekurangan tenaga bidan menambah beban kerja bidan.

Dari segi dana bahwa alokasi dana khusus program dari Dinas Kesehatan Kabupaten, belum ada. Untuk mengatasi permasalahan dana puskesmas menggunakan dana BOK untuk kegiatan sosialisasi yang baru dilaksanakan sekali. Transport rujukan dukun belum bisa di klaim karena dana BOK dalam proses pencairan.

Sarana prasarana yang digunakan yakni sarana prasarana KIA yang sudah ada di puskesmas dan polindes, sarana transportasi 
darat semua puskesmas menggunakan mobil ambulance namun sarana transportasi laut berupa perahu johnson yang digunakan selama ini rusak dan belum ada perbaikan.

Aspek process yang meliputi pelaksanaan yakni sosialisasi bidan ke dukun hanya menjelaskan tentang penghilangan peran dukun dalam pertolongan persalinan yang dalam pelaksanaannya, dukun akan menghubungi bidan dalam menolong persalinan, namun ini belum berjalan dengan baik

Ditinjau dari efektivitas Output kemitraan bidan dengan dukun adalah masih terdapat 195 (89\%) dukun belum bermitra dari 219 dukun yang ada, jumlah rujukan dukun dan akseptor KB pasca bersalin tidak diketahui karena tidak ada pencatatan dan pelaporan data tersebut, terdapat penurunan cakupan pelayanan $\mathrm{K} 1, \mathrm{~K} 4$ dan persalinan nakes dari tahun 2011 ke 201 di Kabupaten Fakfak. Hal ini dapat dikatakan bahwa pelaksanaan program belum berjalan efektif.

\section{SARAN}

Bagi Dinas Kesehatan Kabupaten Fakfak agar Rekruitment tenaga bidan yang masih magang di Rumah Sakit dengan memberikan honor dan ditempatkan di daerah yang masih kurang tenaga bidan dengan fasilitas tempat tinggal yang memadai.

Mengalokasikan anggaran khusus program kemitraan dan bila tidak memungkinkan menambah alokasi dana BOK untuk proggam kemitraan atau sesuai dengan kegiatan program dilapangan.
Membuat terobosan revolusioner dengan Pemerintah Daerah agar tidak menambah jumlah dukun baru, maka anak perempuan atau cucu dukun, disekolahkan untuk jadi bidan dengan biaya ditanggung Pemerintah Daerah.

\section{DAFTAR PUSTAKA}

1. Amilda NL. 2010. Faktor-Faktor Yang Berhubungan Dengan Pemilihan Persalinan Oleh Dukun Bayi. Universitas Diponegoro.

2. Anggorodi R. 2009,. Dukun Bayi Dalam Persalinan Oleh Masyarakat Indonesia. Makara, Kesehatan. 1 ed. Jakarta: FKMUI.

3. Azwar A. 2010. Pengantar Administrasi Kesehatan, Surabaya, Bina Rupa Aksara.

4. Depkes RI. 2008. Pedoman Kemitraan Bidan Dengan Dukun, Jakarta, Depkes RI.

5. Notoatmodjo S. 2007. Promosi Kesehatan dan Ilmu Perilaku, Jakarta, Rineka Cipta.

6. Wijono D. 1997. Manajemen Kepemimpinan Dan Organisasi Kesehatan, Surabaya, Airlangga University Press.

7. Women Research Institute. 2007,. Akses dan Pemanfaatan Fasilitas Kesehatan dan Pelayanan Kesehatan pada Perempuan Miskin [Online]. Jakarta: Women Research Institute. Available: http://www.wri.or.id [Accessed 14 Januari 2012]. 